\title{
COMPARISON OF MATERNAL B12 AND FOLATE STATUS IN PRENATALLY DIAGNOSED NEURAL TUBE DEFECTS: A CASE-CONTROL STUDY
}

\author{
PRENATAL FETAL NÖRAL TÜP DEFEKTI TANISI KONULAN ANNELERDE SERUM B12 \\ VE FOLAT DÜZEYLERININ KARŞILAŞTIRILMASI: VAKA-KONTROL ÇALIŞMASI
}

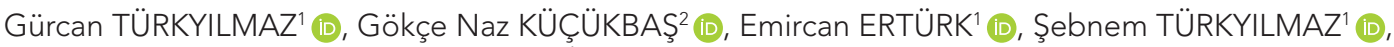 \\ Onur KARAASLAN² (D), Hanım Güler ŞAHIN² (1)
}

'Van Education and Research Hospital, Department of Obstetrics and Gynecology, Van, Turkey

${ }^{2}$ Yüzüncü Yıl University, Department of Obstetrics and Gynecology, Van, Turkey

ORCID IDs of the authors: G.T. 0000-0002-5514-0233; G.N.K. 0000-0002-2755-3700; E.E. 0000-0003-0169-6903; Ş.T. 0000-0002-3984-5663; O.K. 0000-0002-4599-1173; H.G.Ş. 0000-0002-8596-0734

Cite this article as: Turkyilmaz G, Kucukbas GN, Erturk E, Turkyilmaz S, Karaaslan O, Sahin HG. Comparison of maternal B12 and folate status in prenatally diagnosed neural tube defects: A case-control study. J Ist Faculty Med 2020;83(4):325-9. doi: 10.26650/IUITFD.2019.0102

\section{ABSTRACT}

Objective: To evaluate folate and B12 levels in fetuses who had been diagnosed with neural tube defects (NTDs) and healthy fetuses in Van Yüzüncü Y।l University and Van State Education and Research hospitals between March-August 2019.

Material and Method: Thirty-eight pregnant women who had been diagnosed with fetuses with NTDs prenatally, and 40 healthy controls were recruited. The chi-square test and Mann-Whitney $U$ test were employed to compare variables.

Results: None of the women had taken folic acid preconceptionally in the NTD group. However, 4 (10\%) women had taken folic acid supplementation in the preconception period in the control group, and this was significantly different among the groups $(p=0.04)$. The women who had taken folic acid in the first trimester of pregnancy were $9(23.6 \%)$ and $32(80 \%)$ in cases and controls, respectively, and it was significantly different $(p=0.01)$. The mean B12 level was $248.7 \pm 65.4 \mathrm{ng} / \mathrm{ml}$ in cases and $239.3 \pm 27.5 \mathrm{ng} / \mathrm{ml}$ in controls, and there was no significance between the groups $(p=0.78)$. The mean folate level was $9.6 \pm 4.8 \mathrm{ng} / \mathrm{ml}$ in cases and $9.8 \pm 3.9 \mathrm{ng} /$ $\mathrm{ml}$ in controls, and it was similar between the groups $(p=0.62)$.

Conclusion: We did not show difference in folate and B12 levels. However, folic acid intake in preconception or in the first trimester of pregnancy was significantly higher in women who have healthy babies compared to the NTD group.

Keywords: Folate, neural tube defect, prenatal, supplementation, vitamin B12

\section{ÖZET}

Amaç: Van Yüzüncü Yıl Üniversitesi ve Van Eğitim ve Araştırma Hastanesi'nde NTD tanısı koyulan ve sağlıklı fetüsü olan gebelerin B12 ve folat düzeyini karşılaştırdık.

Gereç ve Yöntem: NTD tanısı koyulan 38 hasta ve 40 kontrol grubu çalışmaya dahil edildi. İstatistiksel analizde ki-kare testi ve Mann-Whitney U testi kullanıldı.

Bulgular: NTD grubunda hiçbir hastada prekonsepsiyonel dönemde folik asit kullanımı yoktu ancak kontrol grubunda 4 (\%10) hastada prekonsepsiyonel folik asit kullanımı mevcuttu ve bu fark istatistiksel olarak anlamlıydı $(p=0,04)$. NTD grubunda 9 (\%23.6), kontrol grubunda 32 (\%80) hastada ilk trimesterde folik asit desteği alınmıştı ve bu istatistiksel olarak anlamlıydı $(p=0,01)$. Ortalama B12 seviyesi NTD grubunda $248.7 \pm 65.4 \mathrm{ng} / \mathrm{ml}$, kontrol grubunda 239.3 \pm 27.5 saptandı ve bu fark anlamlı değildi $(p=0,78)$. Ortalama folat seviyesi NTD grubunda $9.6 \pm 4.8 \mathrm{ng} / \mathrm{ml}$, kontrol grubunda $9.8 \pm 3.9 \mathrm{ng} / \mathrm{ml}$ saptandı ve bu fark anlamlı değildi $(p=0,62)$.

Sonuç: Her iki grup arasında B12 ve folat seviyeleri farklı değildi ancak, sağlıklı bebeği olan grupta prekonsepsiyonel dönemde ve ilk trimesterde folik asit kullanımı NTD grubuna göre anlamlı olarak daha fazlaydı.

Anahtar Kelimeler: Folat, nöral tüp defekti, prenatal, vitamin B12

Corresponding author/iletişim kurulacak yazar: gurcanturkyilmaz@gmail.com

Submitted/Başvuru: 18.12.2019 • Revision Requested/Revizyon Talebi: 20.03.2020 •

Last Revision Received/Son Revizyon: 25.03.2020 • Accepted/Kabul: 09.05.2020 • Published Online/Online Yayın: 18.09.2020

(C)Telif Hakkı $2020 \mathrm{~J}$ Ist Faculty Med - Makale metnine jmed.istanbul.edu.tr web sayfasından ulaşılabilir.

(C) Copyright 2020 by J Ist Faculty Med - Available online at jmed.istanbul.edu.tr 


\section{INTRODUCTION}

Neural tube defects (NTDs) are a spectrum of abnormalities that arise as a result of nonclosure of the neural tube until six weeks of gestation (1). Numerous types of NTDs are defined, including acrania, anencephaly, iniencephaly, craniorachischisis, encephalocele, and meningomyelocele. They are the most common central nervous system anomalies, and the incidence varies from 5/1000 to $0.5 / 1000$ (2). Etiology of NTDs is considered multifactorial involving genetic predisposition and environmental factors such as nutritional deficiencies and drug exposure (3). Most NTDs occur sporadically, and in most affected pregnancies, there are no recognizable risk factors.

Epidemiologic studies more than 30 years ego showed a correlation between maternal folate status and NTDs (4). The administration of folic acid before and during the first weeks of gestation can reduce the incidence of NTDs by roughly $70 \%$ but can not prevent it completely; other factors must be involved (5). Furthermore, some studies suggest that nutrients other than folate, such as vitamin B12, may also be essential to neural tube closure and have a potential role in risk reduction $(6,7)$. Vitamin 12 is a fundamental cofactor for two enzymes in DNA synthesis, including folate-dependent methionine synthesis and folate independent methyl malonyl-CoA mutase (8). Similar to folic acid, vitamin B12 deficiency also predisposes to NTDs, and vitamin B12 intake with folic acid may reduce NTDs risk.

Although numerous studies have established the role of folic acid and vitamin B12 associated with NTDs risk, regarding the high prevalence of NTDs and the lack of reviews about the role of maternal folate and vitamin B12 levels in NTDs in the Eastern region of the country, we conducted this study to evaluate the association of maternal folate and vitamin B12 levels with NTDs.

\section{MATERIAL AND METHOD}

This prospective case-control study was conducted between March-August 2019 in Van Education and Research hospital and Van Yüzüncü Yıl University hospital. Those two hospitals are referral centers around the eastern region of Turkey. The NTD group consisted of 38 women who had been diagnosed with fetuses with NTDs prenatally. The control group consisted of 40 pregnant women who did not have a history of NTDs in previous pregnancies and who did not have fetuses with NTDs in the present pregnancy; also, maternal serum alfa fetoprotein (msAFP) levels were in the normal range between 16-20 weeks of gestations. Maternal clinic and demographic features such as gestational weeks at diagnosis, education status, folic acid intake in the preconception period, and folic acid intake in the first trimester were recorded.

Each woman was evaluated with regular ultrasound assessments, which were performed transabdominally using an abdominal 2-5 Mhz curvilinear transducer (Voluson, General Electric, Milwaukee, WI, USA). Fetal NTDs were diagnosed with a detailed ultrasonographic evaluation with high (msAFP) levels. MsAFP levels were measured after ultrasonographic examination in our clinics. Postnatal or postmortem confirmation of NTDs cases were verified.

Serum was separated from blood collected without anticoagulants for vitamin B12 and folate analysis. Radioimmunoassay using gamma counter (Genesis-USA) was used for serum folate and vitamin B12 measurements. Serum folate and vitamin B12 less than five $\mathrm{ng} / \mathrm{ml}$ and 160 $\mathrm{pg} / \mathrm{ml}$ were considered as the cut-off values, respectively.

Statistical analyses were performed using SPSS 16.0. The chi-square test and Mann-Whitney $U$ test were employed to compare variables. Statistical significance was established at $p<0.05$.

\section{RESULTS}

The mean age of pregnant women was $24.4 \pm 4.8$ and $25.6 \pm 4.7$ in the NTDs group, and control group, respectively $(p=0.86)$. BMI was $25.5 \pm 4.4 \mathrm{~kg} / \mathrm{m}^{2}$ in cases, and $24.6 \pm 3.9 \mathrm{~kg} / \mathrm{m}^{2}$ in control group and this difference was not significant. The mean gestational weeks at diagnosis

Table 1: The comparison of demographic and clinical features between NTD mothers and controls.

\begin{tabular}{lccc}
\hline & Cases $(\mathbf{n}=\mathbf{3 8})$ & Controls $(\mathbf{n}=\mathbf{4 0})$ & p-value \\
Age & $24.4 \pm 4.8$ & $25.6 \pm 4.7$ & 0.86 \\
Gravity & $3.2 \pm 1.5$ & $2.5 \pm 1$ & 0.69 \\
BMI & $25.5 \pm 4.4$ & $24.6 \pm 3.9$ & 0.73 \\
Gestational weeks at diagnosis & $18.4 \pm 4.2$ & $21.2 \pm 3.3$ & 0.61 \\
Education status & Illiterate: $11(28.9 \%)$ & Illiterate: $10(25 \%)$ & \\
& Primary school: $23(60.5 \%)$ & Primary school: $24(60 \%)$ & \\
& High school: $3(7.8 \%)$ & High school: $3(7.5 \%)$ & \\
Folic acid intake in preconceptional period & University: $1(2.6 \%)$ & University: $3(7.5 \%)$ & 0.04 \\
Folic acid intake in first trimester & $0(0 \%)$ & $4(10 \%)$ & 0.01 \\
\hline
\end{tabular}


were $18.4 \pm 4.2$ weeks, and the mean gestational weeks at routine ultrasonographic evaluation in controls was $21.2 \pm 3.3(p=0.61)$ and there was no significant difference. Anencephaly in 10 (26.3\%), encephalocele in 4 (10\%), and meningomyelocele in 24 (63.1\%) cases composed the NTDs group. $78.9 \%$ of cases and $75 \%$ of controls were illiterate or primary school graduated. None of the women had taken folic acid preconceptionally in cases. However, $4(10 \%)$ women had taken folic acid supplementation in the preconception period in the control group, and this was significantly different among groups $(p=0.04)$. Women who took folic acid in the first trimester of pregnancy were 9 (23.6\%) and 32 (80\%) in cases and controls, respectively, and it was significantly different $(p=0.01)$. The mean B12 level was $248.7 \pm 65.4 \mathrm{ng} / \mathrm{ml}$ in cases and $239.3 \pm 27.5$ $\mathrm{ng} / \mathrm{ml}$ in controls, and there was no significance between groups ( $p=0.78$ ). The mean folate level was $9.6 \pm 4.8 \mathrm{ng} / \mathrm{ml}$ in cases and $9.8 \pm 3.9 \mathrm{ng} / \mathrm{ml}$ in controls, and it was similar between cases and controls ( $p=0.62)$. The comparison of demographic and clinical features between NTD mothers and controls is demonstrated in Table 1. The values of folate and vitamin B12 levels and p-values between NTDs mothers and controls are shown in Table 2.

Table 2: The comparison of demographic and clinical features between NTD mothers and controls.

\begin{tabular}{lccc}
\hline & Case & Control & $\mathbf{p}$ \\
Folate $(\mathrm{ng} / \mathrm{ml})$ & $9.6 \pm 4.8$ & $9.8 \pm 3.9$ & 0.62 \\
B12 $(\mathrm{pg} / \mathrm{ml})$ & $248.7 \pm 65.4$ & $239.3 \pm 27.5$ & 0.78 \\
\hline
\end{tabular}

\section{DISCUSSION}

NTDs are multifactorial disorders with many genetic and environmental factors defined in the etiology. The development of the neural tube is a multi-step process which is controlled by numerous genes and modulated by environmental factors.

Folate cycles between molecules in specific biologic reactions carry one-carbon groups from other molecules to homocysteine to form methionine. This folate cycle is a vital biochemical reaction required for proper DNA synthesis, repair, and methylation. Thus, low folate levels can directly limit its availability to cells or indirectly disrupt methionine metabolism, thereby increasing homocysteine.

Correlation of serum folate concentrations and NTDs risk has been investigated widely in the literature, and results are controversial. Cech et al. showed that serum folate levels were significantly lower in the NTDs group than controls in their study, which involved 107 pregnant women with NTDs and 275 controls (9). Zhang et al. who compared 82 pregnancies with fetal NTDs and 110 controls, identified lower serum levels of folate and vitamin B12 in the NTDs group (10).
On the contrary, several other researchers showed no relationship. Mobasheri et al. reported that levels of folate and vitamin B12 did not significantly affect NTDs risk in their study (11). Aydın et al. evaluated serum folate and vitamin B12 levels in 35 pregnant women with NTDs fetuses and 38 controls. They revealed no relation between either vitamin B12 and folate levels and NTDs. (12). In our study, we did not show lower serum folate levels among the NTDs group.

The starting of folic acid intake before conception is fundamental to reduction of NTDs risk and folate given before and during the first four weeks of gestation can prevent more than half of NTDs. (13). Unfortunately, many pregnancies are unplanned, and women often do not know that they are pregnant until the crucial first 4 to 8 weeks of pregnancy. This is the time during which neural tube development occurs, hence the importance of ensuring adequate folic acid intake before pregnancy. Thus, in many countries such as the USA, food fortification programs have been launched to prevent neural NTDs without vitamin supplementation (14). In our county, there is no food fortification program, and folic acid supplementation in the appropriate period is crucial to reduce NTDs risk. In our study, folic acid intake was significantly higher in controls either in the preconception period or in the first trimester of pregnancy. This data shows that folic acid intake in the proper period of pregnancy may reduce NTDs risk; even serum folate levels were not significantly different among groups.

Since the etiology of NTDs is multifactorial, folic acid supplementation alone is not sufficient to entirely prevent NTDs. Vitamin B12 is a fundamental cofactor for two enzymes in DNA synthesis and may influence NTDs risk in pregnancy. Ray et al. showed significantly low maternal serum B12 levels in pregnancies with NTDs in their population-based study (2). Kirke et al. evaluated 81 pregnant women with NTDs and 247 controls and showed significantly lower vitamin B12 levels among NTDs cases compared with the controls (15). Molloy et al. compared vitamin B12 status in women who had NTDs in current pregnancy and who had NTDs affected child in a previous pregnancy with healthy controls. They found that inadequate vitamin B12 levels were associated with a significantly increased risk for NTDs. Furthermore, they suggested women keep optimum vitamin B12 levels above $300 \mathrm{ng} / \mathrm{L}$ (16).

Contrastingly, Ceyhan et al. assessed serum folate and vitamin B12 levels in 31 pregnant women with NTDs fetuses and 32 controls. They revealed no relation between either vitamin B12 and folate levels and NTDs (17). We did not show a significant difference in vitamin B12 levels between the two groups in our study.

Methionine synthase is a vitamin B12 dependent enzyme, and in the absence of vitamin B12 or folate, homocyste- 
ine accumulates in the serum. Thus, increased serum homocysteine levels may be an indicator of folate or vitamin B12 deficiency. Mills et al. showed that pregnant women who had fetuses with NTDs have significantly higher homocysteine levels than controls in their case-control study (18). Yang et al. showed that mothers with NTDs offspring demonstrated dramatically higher mean plasma homocysteine levels than mothers with healthy offspring in their meta-analysis (19). Unfortunately, we did not measure serum homocysteine levels in our study due to technical paucity.

Recently, among folate-metabolism related genes, MTHRF has been the principal focus of attention. Previous studies have shown that the c.677C > T and c.1298A>C variations are associated with an increased risk of NTDs $(20,21)$. Also, Liu et al. revealed that MTHFR c.677C $>$ T variation was significantly higher in the tissue or blood samples of NTDs fetuses compared to controls (22).

\section{CONCLUSION}

Our data indicate that either maternal folate and vitamin B12 levels are not significantly different among women who have NTDs fetuses compared to controls. Conversely, women who had taken folic acid in the preconception period or first trimester of pregnancy have a significantly lower risk of NTDs offspring. A dietary supplement of folate in the preconception and first weeks of gestation is crucial to prevent NTDs.

Ethics Committee Approval: This study was approved by Van Education and Research Hospital Ethics Committee (20011467).

Informed Consent: Written consent was obtained from the participants.

Peer Review: Externally peer-reviewed.

Author Contributions: Conception/Design of Study- G.T.; Data Acquisition- G.T., G.N.K., O.K., H.G.Ş.; Data Analysis/Interpretation- E.E., Ş.T.; Drafting Manuscript- G.T., E.E., Ş.T.; Critical Revision of Manuscript- H.G.Ş., O.K., G.N.K.; Final Approval and Accountability- G.T., G.N.K., E.E., Ş.T., O.K., H.G.Ş.; Technical or Material Support- E.E.; Supervision- H.G.Ş., G.T.

Conflict of Interest: Authors declared no conflict of interest.

Financial Disclosure: Authors declared no financial support.

Etik Komite Onayı: Bu çalışma için etik kurul onayı Van Eğitim ve Araştırma Hastanesi Etik Kurulu'ndan alınmıştır (20011467).

Bilgilendirilmiş Onam: Katılımcılardan bilgilendirilmiş onam alınmıştır.

Hakem Değerlendirmesi: Dış bağımsız.
Yazar Katkıları: Çalışma Konsepti/Tasarım- G.T.; Veri ToplamaG.T., G.N.K., O.K., H.G.Ş.; Veri Analizi/Yorumlama- E.E., Ş.T.; Yazı Taslağı- G.T., E.E., Ş.T.; İçeriğin Eleştirel İncelemesi- H.G.Ş., O.K., G.N.K.; Son Onay ve Sorumluluk- G.T., G.N.K., E.E., Ş.T., O.K., H.G.Ş.; Malzeme ve Teknik Destek- E.E.; Süpervizyon- H.G.Ş., G.T.

Çıkar Çatışması: Yazarlar çıkar çatışması beyan etmemişlerdir.

Finansal Destek: Yazarlar finansal destek beyan etmemişlerdir.

\section{REFERENCES}

1. Botto LD, Moore CA, Khoury MJ, Erickson JD. Neural-tube defects. N Engl J Med 1999;341(20):1509-19. [CrossRef]

2. Ray JG, Wyatt PR, Thompson MD, Vermeulen MJ, Meier C, Cole DE, et al. Vitamin B12 and the risk of neural tube defects in a folic acid fortfied population. Epidemiology 2007;18(3):362-6. [CrossRef]

3. Greene ND, Stainer P, Copp AJ. Genetics of human neural tube defects. Hum Mol Genet 2009;18 (R2):R113-R129. [CrossRef]

4. Czeizel $A E$, Dudas I. Prevention of the first occurance of neural-tube defects by periconceptional vitamin supplementation. N Engl J Med 1992;327(26):1832-5. [CrossRef]

5. Au KS, Ashley-Koch A, Northrup H. Epidemiologic and genetic aspects of spina bifida and other neural tube defects. Dev Disabil Res Rev 2010;16(1):6-15. [CrossRef]

6. Van Loon K, Besseghir K, Eshkol A. Neural tube defects after infertility treatment: a review. Fertil Steril 1992;58(5):875-84. [CrossRef]

7. Wald NJ, Hackshaw AD, Stone R. Blood folic acid and vitamin B12 in relation to neural tube defects: a case control study. Biol Neonate 1995;67(3):154-9. [CrossRef]

8. Weir DG, Scott JM. Cobalamins: Physiology, dietary sources and requirements. In: Sadler MJ, Strain JJ, Caballero B. eds. Encylopedia of Human Nutrition. San Diego, CA, Academic Press 1999:394-401.

9. Cech I, Burau KD. Serological differences in folate/vitamin B12 in pregnancies affected by neural tube defects. South Med J 2010;103(5):419-24. [CrossRef]

10. Zhang T, Xin R, Gu X, Wang F, Pei L, Zheng Z, et al. Maternal serum vitamin $\mathrm{B} 12$, folate and homocysteine and the risk of neural tube defects in the offspirng in a high risk area of China. Public Health Nutr 2009;12(5):680-6. [CrossRef]

11. Mobasheri E, Keshtkar A, Golalipour MJ. Maternal folate and vitamin B12 status and neural tube defects in northern Iran: a case control study. Iran J Pediatr 2010;20(2):167-73.

12. Aydın H, Arısoy R, Karaman A, Erdogdu E, Cetinkaya $A$, Demirci $O$, et al. Evaluation of maternal serum folate, vitamin B12, and homocysteine levels and factor $V$ Leiden, factor 2 g.20212G $>$ A, and MTHRF variations in prenatally diagnosed neural tube defects. Turk J Med Sci 2016;46(2):489-94. [CrossRef]

13. MRC Vitamin Study Research Group. Prevention of neural tube defects: results of the Medical Research Council vitamin study. Lancet 1991;338(8760):131-7. [CrossRef]

14. Tinker SC, Cogswell ME, Devine O, Berry RJ. Folic acid intake among U.S. women aged 15-44 years, National Health and Nutrition Examination Survey, 2003-2006. Am J Prev Med 2010;38(5):534-42. [CrossRef] 
15. Kirke PN, Molloy AM, Daly LE, Burke H, Weir DG, Scott JM. Maternal plasma folate and vitamin B12 are independent risk factors for neural tube defects. QJM 1993;86(11):703-8.

16. Molloy AM, Kirke PN, Troandle JF, Burke $H$, Sutton M, Mills $\mathrm{JL}$, et al. Maternal vitamin B12 status and risk of neural tube defects in a population with high neural tube defects prevalance and no folic acid fortification. Pediatrics 2009;123(3):917-23. [CrossRef]

17. Ceyhan ST, Beyan C, Atay V, Yaman H, Alanbay I, Başer I, et al. Serum vitamin B12 and homocysteine levels in pregnant women with neural tube defects. Gynecol Endocrinol 2010;26(8):578-81. [CrossRef]

18. Mills JL, Scott JM, Kirke PN, McPartlin JM, Conley MR, Weir DG, Molloy AM, Lee YJ. Homocysteine and neural tube defects. J Nutr 1996;126(3):756-60.

19. Yang M, Li W, Wan Z, Du Y. Elevated homocysteine levels in mothers with neural tube defects: a systematic review and meta-analysis. J Matern Fetal Neonatal Med 2017;30(17):2051-57. [CrossRef]
20. Van der Put NM, Steegers-eunissen RPM, Frosst P, Trijbels FJ, Eskes TK, et al. Mutated methylenetetrahydrofolate reductase as a risk factor for spina bifida. Lancet 1995;346(8982):1070-1. [CrossRef]

21. Shields DC, Kirke PN, Mills JL, Ramsbottom D, Molloy AM, Whitehead AS. The 'thermolabile' variant of methylenetetrahydrofolate reductase and neural tube defects: an evaluation of genetic risk and the relative importance of the genotypes of the embryo and the mother. Am J Hum Genet 1999;64(4):1045-55. [CrossRef]

22. Liu J, Qi J, Yu X, Zhu J, Zhang L, Luo X, et al. Investigations of single nucleotide polymorphisms in folate pathway genes in Chinese families with neural tube defect. J Neurol Sci 2014;337(1-2):61-6. [CrossRef] 